\title{
HOW DO BRAND ASSOCIATIONS AFFECT PURCHASE INTENTIONS? A CASE OF ORGANIC PRODUCTS
}

\author{
Viktorija Grigaliūnaitè, Lina Pilelienè \\ Vytautas Magnus University, Lithuania \\ viktorija.grigaliunaite@vdu.lt; lina.pileliene@vdu.lt
}

\begin{abstract}
The aim of the research is to determine the influence of brand associations on purchase intentions in the framework of organic products. In order to determine the influence of brand associations on purchase intentions in the organic product category, the organic yogurt was chosen as a product. The brands' criteria grid was elaborated for the selection of the specific yogurt brands and three different yogurt brands were chosen for the research. Nine associations directly or indirectly associated with ecology were generated and approved by experts of marketing and advertising; namely: 'organic', 'natural', 'ecological', 'healthy', 'nutritious', 'Lithuanian', 'tasty', 'regular', and 'expensive'. The empirical research with the selected brands and generated associations was composed of two parts: experiment and questionnaire survey. The research results revealed that brand associations have a huge impact on consumer purchase intentions in a framework of organic products. Proper and positive association development positively and directly influences consumer purchase intentions. Positioning of the brand as providing organic products is extremely important when seeking to develop brand associations with organic products; the naturalness, ecology of the product should be emphasised in marketing communication; a brand name should be meaningful and visual marketing communication should expose the ecology. For the future research, the analysis of the influence of brand associations on the conative consumer response in the frameworks of the remaining products categories is necessary.
\end{abstract}

Key words: brand associations, consumer behaviour, purchase intentions, organic products, brand equity.

\section{Introduction}

Framed by the conditions of market economy and a tough competition in the sector, the producers of fast-moving-consumer-goods are facing the situation where the determination of factors affecting consumer purchase intentions becomes vital. Achieving to respond effectively to the ever-changing business environment, brand managers are elaborating new strategies to strengthen brand association which connects images and symbols with a specific brand or its benefits (Virutamasen, Wongpreedee, \& Kumnungwut, 2015). Considering the variety of brands of the same products competing for the customer attention and share of wallet, knowing the keywords for consumer attraction might result in a measurable competitive advantage among the rivals. The previous research (see Liesionis \& Pileliene, 2009; Pilelienè \& Liesionis, 2014) enabled the determination of product attributes influencing milk consumer's choice in Lithuania. The results of the research showed that the key determinants of the milk product's choice are such factors as naturalness and the country-of-origin (Lithuanian milk consumers strictly prefer local producers' goods). Therefore, considering latter results it might be assumed that naturalness and local origination can also affect the choice of other products representing fast-movingconsumer-goods sector in Lithuania. Moreover, the trend for the ecology and organic production has been obvious in Lithuania in recent years. On the other hand, the producers of organic agricultural and food products often face grater expenditures and the final price for consumer increases. Therefore, ecology is related to expensiveness. Analysing the effect of country-of-origin on consumers' choice (see Šontaitè-Petkevičienè \& Pilelienè, 2013; Pilelienè \& Šontaitè-Petkevičienè, 2014), it was determined that despite being a shortage in other sectors, in a food product sector 'made in Lithuania' can be used as a promotional tool. Considering latter results, an assumption is made that associating a brand with ecology and a proper country-of-origin might lead to a better consumers' opinion and brand valuations in terms of increased purchase intentions. The other previous research (Pilelienè, Grigaliūnaitè, \& Stakauskaite, 2016) indicated that colours might have an influence on consumer perception, valuation of a product, and purchase intentions. Therefore, another premise for this research is that brand associations are colour-related.

Considering all the discussed insights, the object of this research is brand associations, which influence purchase intentions of organic products. The scientific problem analyzed in the article is formulated by a question: how and what brand associations influence purchase intentions for organic products? The aim of the research is to determine the influence of brand associations on purchase intentions in the framework of organic products. Accordingly, this research fills the gap in the scientific literature by determining the influence of brand associations on purchase intentions in the framework of organic products. Moreover, the findings of this study have specific practical implications of how to position brands in the market in order to enhance the possibility of higher sales of organic products. 


\section{Materials and Methods}

For the analysis of the influence of brand associations on purchase intentions in the case of organic products, the specific product - organic yogurt was chosen for the experiment as it represents the category of fast-moving-consumer-goods, hence the analysis of purchase intentions becomes more reliable. Authors made the yogurt brands' criteria grid (see Table 1) for the selection of the specific brands. After the selection, three different yogurt brands remained for the experiment. As it can be seen, the first yogurt brand $\mathrm{A}$ is foreign, with foreign brand name is associated with health. The dominating colours in the logotype are green and white and fruits are presented on the packaging. Brand A yogurts are sold in Lithuania with the average price when compared to the competitors and latter brand is positioned in the market as healthy, nutritious, and superior quality. The second brand $\mathrm{B}$ is Lithuanian with Lithuanian brand name meaning the native herb. It is sold in Lithuania with the high price when compared to the competitors. The dominating colours in the logotype are green and white and Lithuanian herb corresponding to the brand name is incorporated in the logotype. The latter brand is positioned in the market as organic, natural, healthy, and nutritious. The third brand $\mathrm{C}$ is Lithuanian with Lithuanian brand name corresponding to the generic company name. It is sold in Lithuania with the low price when compared to the competitors. Many pastel colours and colourful fruits are presented on the packaging. The latter brand is positioned in the market as Lithuanian, healthy, nutritious, tasty, and natural. Consequently, all three chosen organic yogurt brands are generally known for the consumers in the experiment holding country.
To reach the aim of the article, nine associations at some level directly or indirectly associated with ecology were generated and approved by experts of marketing and advertising. The generated associations for the experiment are 'organic', 'natural', 'ecological', healthy', 'nutritious', 'Lithuanian', 'tasty', 'regular', 'expensive'.

The empirical research with selected yogurt brands and generated associations was composed of two parts: experiment and questionnaire research.

The aim of the experiment was to determine the implicit associations with each of the selected brands. In this research for the measurement of implicit associations Inquisit's Brand Association Reaction Time Task by Millisecond Software was applied. Latter Task measures reaction time of judgments whether words (generated associations) are associated with the selected brands. Till et al. (2011) stated that strength of association is defined as the intensity of the connection between the association and the brand node, and it is measured by the response latency. Hence, faster response latency indicates stronger association.

Participants viewed brand names in the computer screen (diameter $-58 \mathrm{~cm}$ ) and shortly thereafter were presented a possible association with that brand. They were asked to decide as fast as possible whether the association belongs to the brand (yes) or not (no) by pressing the response buttons (left/right). The assignment of yes/no to left and right response button was counterbalanced by an assigned group number. The experimental procedure contained 1 practice block of 8 trials (2 practice brands $\mathrm{x} 4$ associations) and 1 experimental block of 27 trials (3 brands x 9 associations). All brands were tested

Criteria of chosen yogurt brands

Table 1

\begin{tabular}{|c|c|c|c|c|c|c|c|}
\hline \multirow[b]{2}{*}{ Brand } & \multicolumn{7}{|c|}{ Criteria } \\
\hline & $\begin{array}{c}\text { Country of } \\
\text { origin }\end{array}$ & Name & $\begin{array}{c}\text { Meaning of } \\
\text { name }\end{array}$ & Logotype & Positioning & Price & $\begin{array}{c}\text { Sold in } \\
\text { Lithuania }\end{array}$ \\
\hline A & Foreign & Foreign & $\begin{array}{l}\text { Foreign, but } \\
\text { associated } \\
\text { with health }\end{array}$ & $\begin{array}{l}\text { - Dominating colours: } \\
\text { green and white } \\
\text { - Fruits are presented } \\
\text { on the packaging }\end{array}$ & $\begin{array}{l}\text { - Healthy } \\
\text { - Nutritious } \\
\text { - Superior quality }\end{array}$ & Average & Yes \\
\hline B & Lithuanian & Lithuanian & $\begin{array}{l}\text { Lithuanian } \\
\text { herb name }\end{array}$ & $\begin{array}{l}\text { Dominating colours: } \\
\text { green and white } \\
\text { Picture of Lithuanian } \\
\text { herb is incorporated in } \\
\text { the logotype }\end{array}$ & $\begin{array}{l}\text { - Organic } \\
\text { - Natural } \\
\text { - Healthy } \\
\text { - Nutritious }\end{array}$ & High & Yes \\
\hline $\mathrm{C}$ & Lithuanian & Lithuanian & $\begin{array}{l}\text { Generic } \\
\text { Lithuanian } \\
\text { company } \\
\text { name }\end{array}$ & $\begin{array}{l}\text { - Many pastel colours } \\
\text { - Fruits are presented } \\
\text { on the packaging }\end{array}$ & $\begin{array}{l}\text { - Healthy } \\
\text { - Nutritious } \\
\text { - Tasty } \\
\text { - Natural } \\
\text { - Lithuanian }\end{array}$ & Low & Yes \\
\hline
\end{tabular}


in a mixed format, the order of brands was randomly selected; moreover, the order of associations within the brands was randomly selected as well. For the analysis of the experiment results, we applied the results' categorization procedure as described in Till et al. (2011): categorized each brand/association pair as either 'strong' (top 25 percent of response times), 'medium' (middle 50 percent of response times) or 'weak' (bottom 25 percent of response times).

After the experiment, each of the participants' filled the questionnaire (second part of the research). The questionnaire was composed of the measures of explicit associations, purchase intentions, and demographic part. Explicit associations regarding each of the brands were measured with the same associations used in the experiment by applying the scale of semantic differential. Moreover, respondents had to evaluate the level of purchase intentions of each brand in two conditions: 1) when choosing to buy an organic product; 2) when choosing to buy any product (not specifically organic). Finally, respondents had to indicate their age and gender.

The empirical research was held in Lithuania, Vytautas Magnus University, February 2017. 23 participants' (13 females) data appropriate for the analysis were obtained. IBM SPSS Statistics v.20 and XLSTAT 2014 software packages were applied for the statistical analysis of the results.

\section{Results and Discussion}

As the data of Brand Association Reaction Time Test reveal, brand A is strongly associated with 'tasty' and 'nutritious'; has medium association with 'expensive', 'Lithuanian', 'ecological', 'healthy', and 'organic'; and is weakly associated with 'natural' and 'regular' (see Fig. 1). As it can be seen, brand $\mathrm{B}$ is strongly associated with 'ecological' and 'natural'; has medium association with 'expensive', 'nutritious', 'organic', 'tasty', and 'regular'; and is weakly associated with 'Lithuanian' and 'healthy'. Brand $\mathrm{C}$ is strongly associated with 'Lithuanian' and 'regular'; has medium association with 'expensive', 'ecological', 'organic', 'natural', and 'healthy'; and is weakly associated with 'tasty' and 'nutritious'. Consequently, based on the implicit associations, brand $\mathrm{A}$ is associated with good taste and nutrition; brand $\mathrm{B}$ is associated with ecology and natural products, while brand $\mathrm{C}$ is associated with homeland products.

The strength of explicit associations measured by the questionnaire is visualized in Figure 2. As it can be seen, brand $\mathrm{A}$ is strongly associated with 'tasty', 'nutritious', and 'expensive'; has medium association with 'ecological', 'regular', 'healthy', and 'organic'; and is weakly associated with 'natural' and 'Lithuanian'. Brand B is strongly associated with 'ecological', 'natural', 'nutritious', 'healthy', and 'Lithuanian'; has medium association with 'expensive', 'organic'; and is weakly associated with 'tasty' and 'regular'. Brand C is strongly associated with 'Lithuanian', 'tasty' and 'healthy'; has medium association with 'expensive', 'nutritious', 'ecological', and 'natural'; and is weakly associated with 'organic' and 'regular'. Consequently, based on the explicit associations, brand $\mathrm{A}$ is associated with good taste, nutrition, and high price. Hence, in the

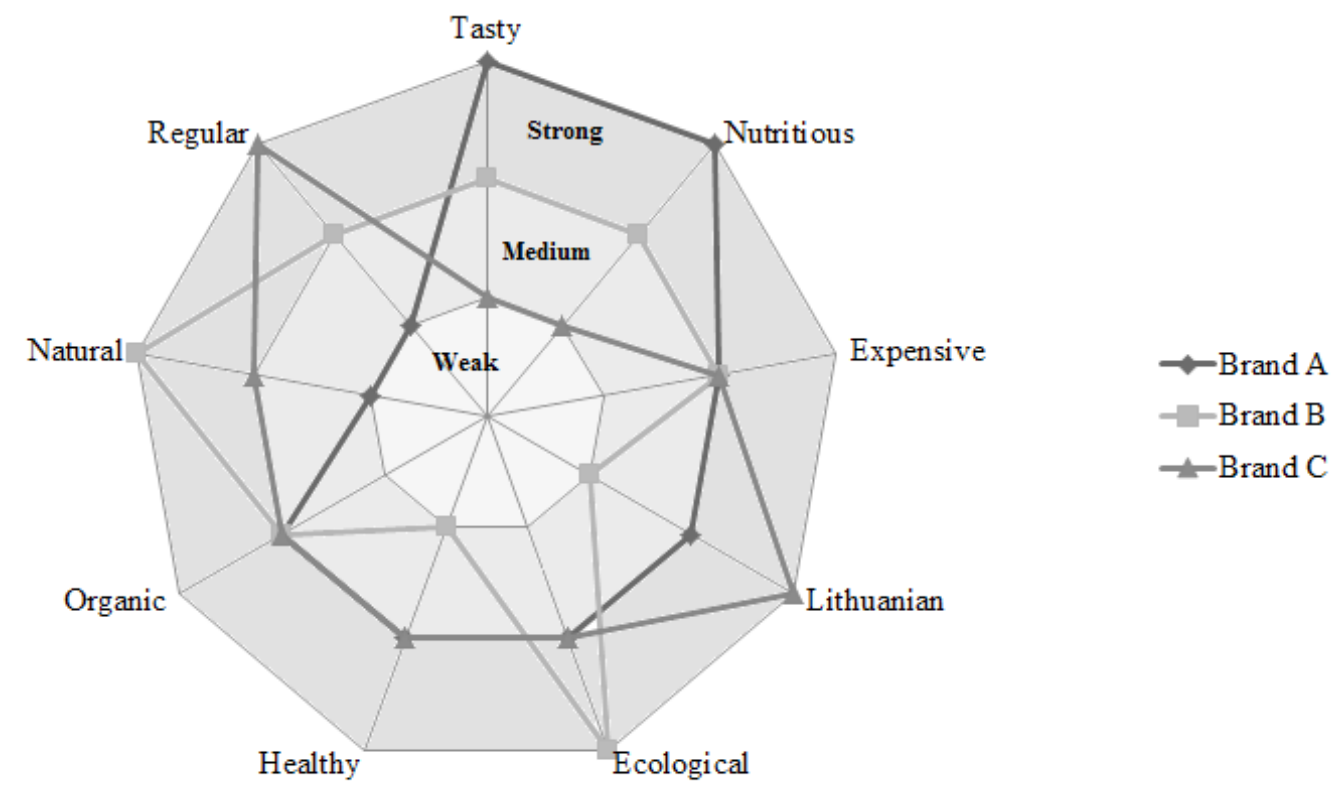

Figure 1. Strength of implicit associations. 

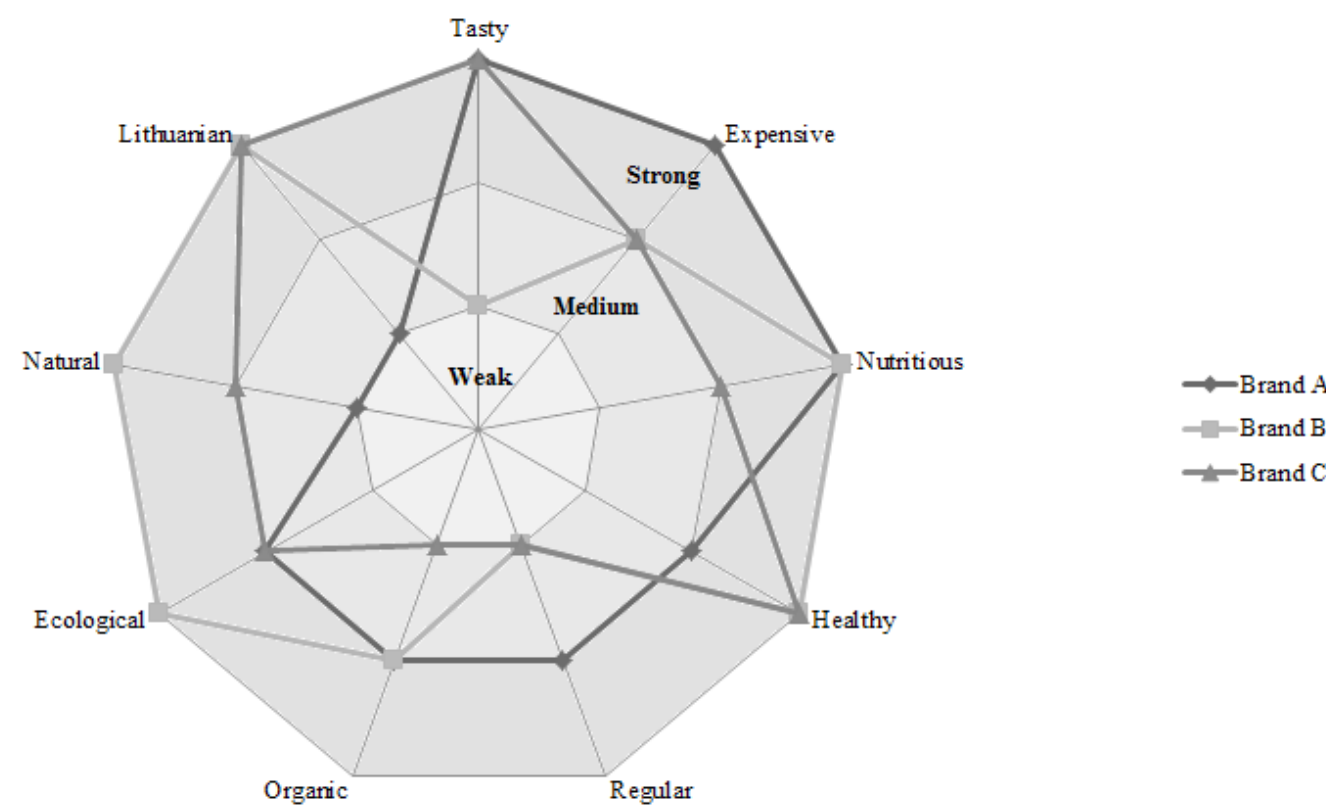

Figure 2. Strength of explicit associations.

case of brand A, implicit associations correspond to the explicit associations. Based on the explicit associations, brand $\mathrm{B}$ is associated with ecology and natural products, thus in the case of brand $\mathrm{B}$, implicit associations correspond to the explicit associations as well. Finally, based on the explicit associations, brand $\mathrm{C}$ is associated with healthy homeland products, which also correspond to the implicit associations. It could be stated that the obtained results of the strength of associations are reliable as the results of response latency and the results of the questionnaire research complement each other.

The analysis of the research results revealed that purchase intentions when choosing to buy an organic product are the highest for the brand $\mathrm{B}$. Hence, the brand that is associated with ecology and natural products is also the most likely to be bought when choosing the organic product. Nevertheless, when choosing to buy any product, not specifically organic, then purchase intentions are the highest for the brand $\mathrm{C}$, which is associated with healthy homeland products. Purchase intentions for the brand A, which is associated with good taste, nutrition, and high price, are the lowest regarding both cases, when choosing organic product and when choosing any product.

As the object of this research is brand associations, which influence purchase intentions of organic products and the questionnaire data are non-normally distributed, the Friedman test is applied (three dependent samples) in order to evaluate whether there are significant differences in purchase intentions when choosing an organic product. As the test revealed, there are significant differences in purchase intentions when choosing an organic product. To examine where the differences actually occur, Wilcoxon Signed Ranks Test with the Bonferroni adjustment (significance

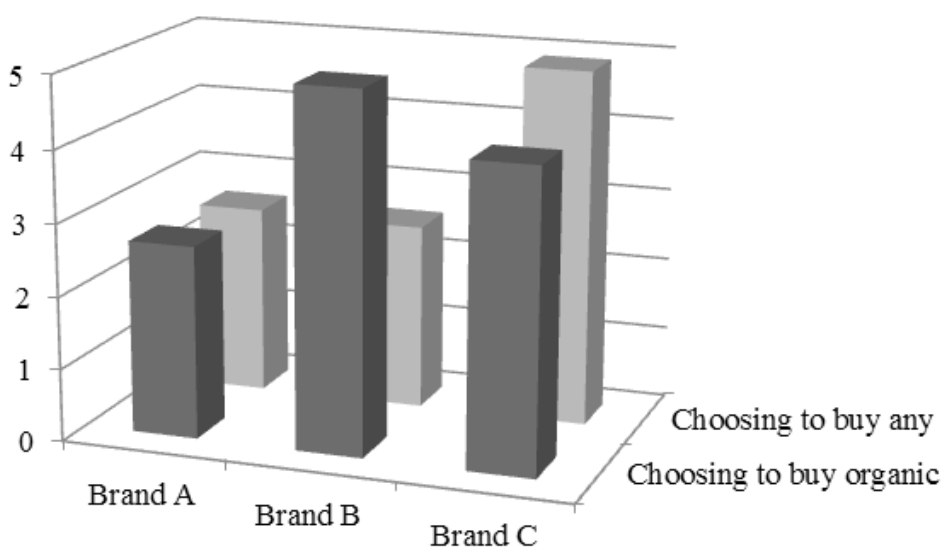

- Choosing to buy organic

Choosing to buy any

Figure 3. Evaluations of purchase intentions. 
Wilcoxon Signed Ranks Test

\begin{tabular}{|c|c|c|c|}
\hline Statistics & Organic A - Organic B & Organic C - Organic B & Organic C - Organic A \\
\hline $\mathrm{Z}$ & 3.020 & 1.205 & 3.037 \\
\hline p value & 0.003 & 0.228 & 0.002 \\
\hline
\end{tabular}

Table 3

Standardized Regression Coefficients

\begin{tabular}{|c|c|c|c|c|c|c|}
\hline Source & Value & $\begin{array}{c}\text { Standard } \\
\text { error }\end{array}$ & $\mathrm{t}$ & $\mathrm{p}$ value & $\begin{array}{c}\text { Lower bound } \\
(95 \%)\end{array}$ & $\begin{array}{c}\text { Upper bound } \\
(95 \%)\end{array}$ \\
\hline $\begin{array}{c}\text { Associations of Brand B -> Choosing to } \\
\text { buy organic product }\end{array}$ & 0.615 & 0.181 & 3.396 & 0.003 & 0.236 & 0.993 \\
\hline $\begin{array}{c}\text { Associations of Brand C-> Choosing to } \\
\text { buy organic product }\end{array}$ & 0.643 & 0.176 & 3.658 & 0.002 & 0.275 & 1.000 \\
\hline
\end{tabular}

level equals to 0.017) is applied as the Post-Hoc test (see Table 2). Purchase intentions when choosing organic product differ statistically significantly for brand $B$ and for brand $A(p<0.01)$ as well as for brand $\mathrm{C}$ and for brand $\mathrm{A}(\mathrm{p}<0.01)$. Consequently, when choosing organic product, brand $\mathrm{B}$ or brand $\mathrm{C}$ are statistically significantly more likely to be bought when compared to the brand A. On the other hand, the difference in purchase intentions when choosing organic product of brand B and brand $\mathrm{C}$ is statistically non-significant, even though purchase intentions for the brand $\mathrm{B}$ are a little higher. Based on these results, brand $\mathrm{A}$ is eliminated from the further analysis as purchase intentions for latter brand are statistically significantly lower.

In order to determine the influence of brand associations on purchase intentions in the case of organic products, simple linear regression analysis is conducted and the results are provided in the Table 3 below. As it can be seen, associations of brand B have positive statistically significant $(p<0.01)$ influence on the purchase intentions when choosing to buy an organic product. Moreover, associations of brand $\mathrm{C}$ have positive statistically significant $(\mathrm{p}<0.01)$ influence on the purchase intentions when choosing to buy an organic product as well.

The visualized regression line of organic product purchase intentions by associations in the case of brand $\mathrm{B}$ is presented in the Figure 4 below. When analyzing brand $\mathrm{B}$, it can be seen that the value of the determination coefficient is 37.8 percent. Hence, the explained variance of brand $B$ related purchase intentions is considered as moderate. The visualized regression line reflects the trend of growing purchase intentions of brand $\mathrm{B}$ with the growing level of positive associations with the brand $\mathrm{B}$. The analysis of the influence of all the specific associations on the brand $\mathrm{B}$ purchase intentions reveals that the most important associations of the brand B that influence purchase intentions are 'ecological', 'natural', 'healthy', 'expensive', and 'organic'.

The visualized regression line of organic product purchase intentions by associations in the case of brand $\mathrm{C}$ is presented in the Figure 5 below. When analyzing brand $\mathrm{C}$, it can be seen that the value of the determination coefficient is 41.3 percent. Thus, the explained variance of brand $\mathrm{C}$ related purchase intentions is considered as moderate to high. The visualized regression line reflects the trend of growing purchase intentions of brand $\mathrm{C}$ with the growing level of positive associations with the brand $\mathrm{C}$ as well. The analysis of the influence of all the specific associations on the brand $\mathrm{C}$ purchase intentions reveals that the most important associations of the brand $\mathrm{C}$ that influence purchase intentions are 'Lithuanian', 'natural', 'healthy', 'ecological', and 'nutritious'.

The analysis of the research results reveals that brand B is associated with ecology and healthy natural products and these associations influence consumer purchase intentions when choosing an organic product. The assumption can be made that despite the fact that brand B is Lithuanian, it is not strongly associated as being such. Nevertheless, the positioning of the brand as organic, natural, healthy, and nutritious, showing green and white colours together with green native herbs in the logotype and the brand name itself being of native herb leads to the improved associations of an organic product.

Brand $\mathrm{C}$ is associated with healthy and ecological homeland products and these associations influence consumer purchase intentions when choosing either organic or any product. Brand $\mathrm{C}$ is positioned as Lithuanian, tasty, healthy and nutritious due to the natural ingredients from the homeland. The name of the brand $\mathrm{C}$ is generic Lithuanian company name; there are many pastel colours and many colourful 

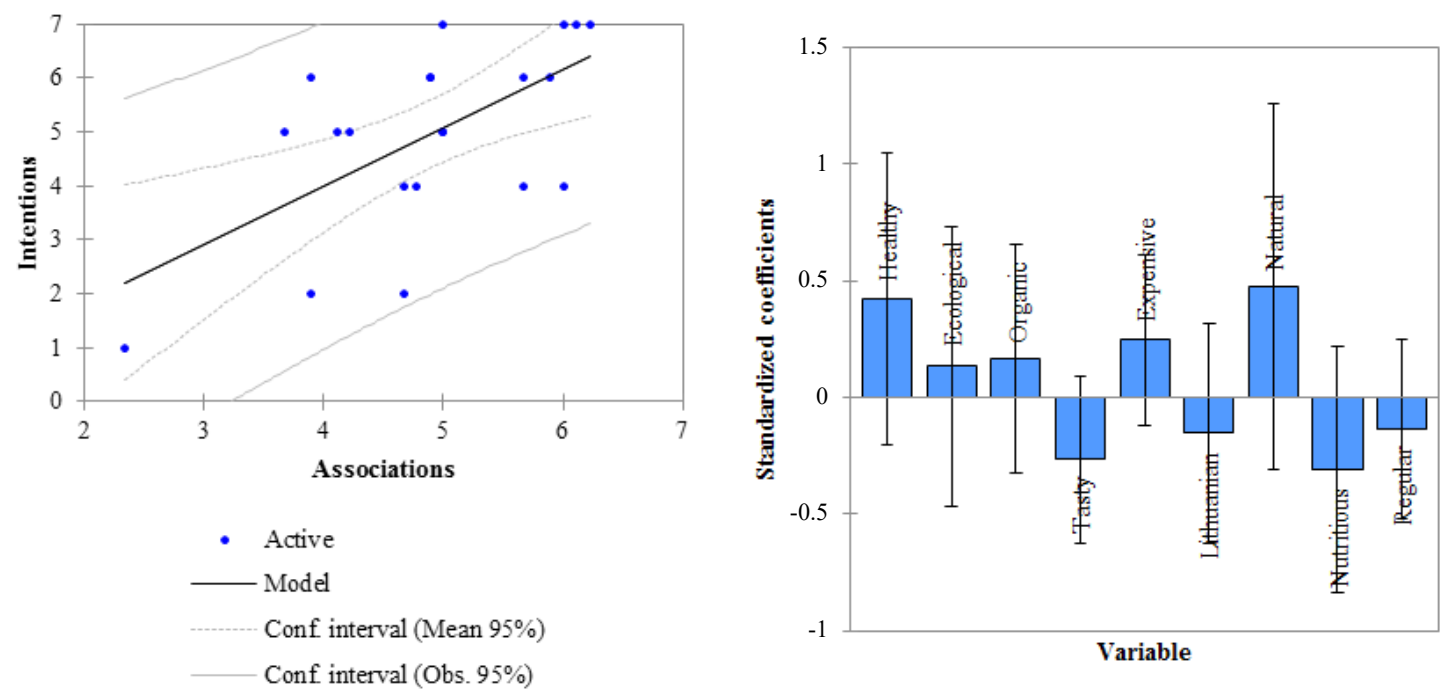

Figure 4. Regression of organic product Purchase Intentions by Associations in a case of brand $B\left(\mathrm{R}^{2}=0.378\right)$.
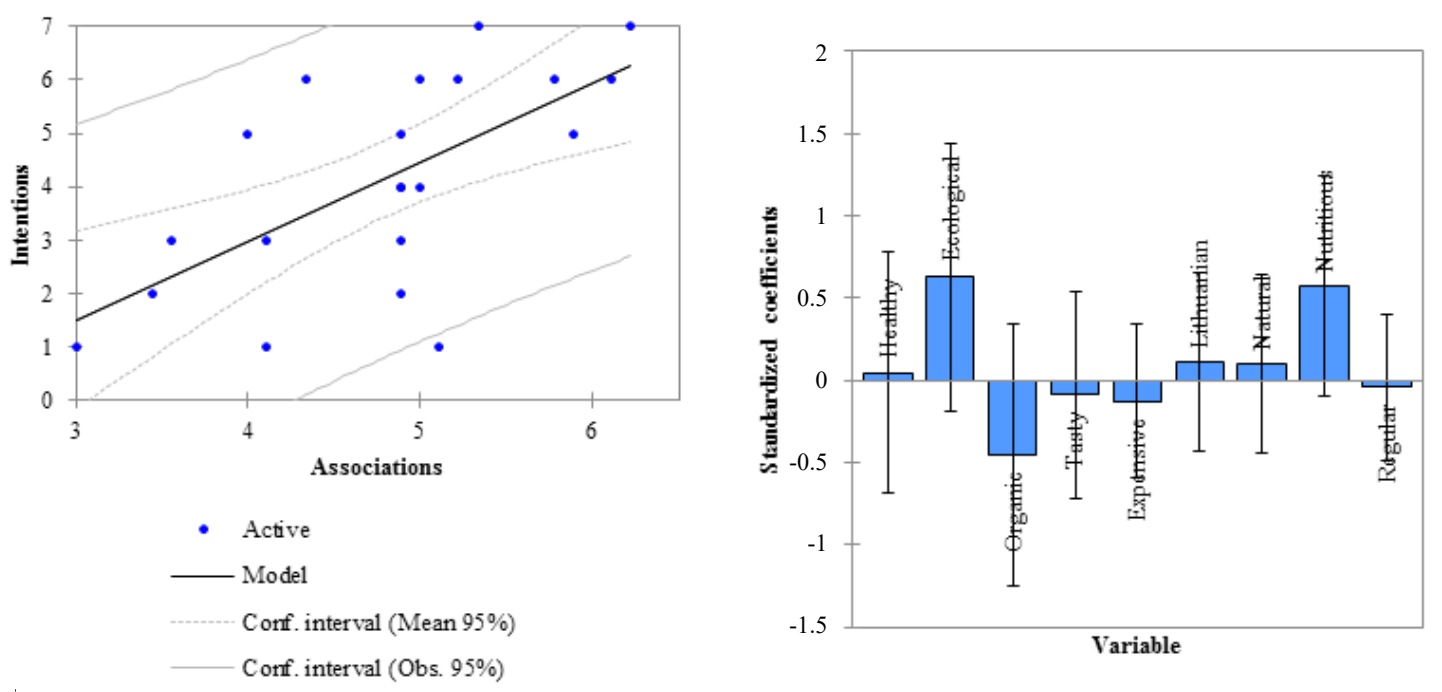

Figure 5. Regression of organic product Purchase Intentions by Associations in a case of brand $C\left(\mathrm{R}^{2}=0.413\right)$.

fruits presented on the packaging. Hence, the emphasis in the positioning regarding brand $\mathrm{C}$ is on the natural ingredients from the homeland. Consequently, this leads to the strong brand $\mathrm{C}$ associations with healthy homeland products, and despite this brand has no strong direct associations with organic products, its associations indirectly create the impression of an organic product, thus leading to enhanced purchase intentions when choosing an organic product.

\section{Conclusions}

The producers of fast-moving-consumer-goods are facing the intensifying competition in the sector; therefore, the determination and assessment of factors affecting consumer purchase intentions might lead to the improved marketing communication as well as better results in terms of revenues and profits. Many brands of similar products compete for the customer attention and share of wallet; therefore, formation of the right brand associations becomes a necessary task of brand management.

Brand associations have a huge impact on consumer purchase intentions in a framework of organic product category. Developing proper and positive associations positively and directly influence consumer purchase intentions. Contrarily, the assumption can be made that developed negative or improper associations can negatively influence consumer purchase intentions.

Based on the analysis of research results, it could be stated that positioning of the brand as providing organic products is extremely important when seeking to develop brand associations with organic products. The naturalness, ecology of the product should be emphasised in marketing communication. Moreover, 
brand name should be meaningful and visual marketing communication should expose the ecology. Such means can enhance the possibility to develop a brand associated with certainly organic products.

Nevertheless, the analysis of the research results leads to the conclusion that in the positioning process, strong emphasis of the natural ingredients, precisely from the homeland stimulates consumers to believe consciously or unconsciously that a product is more likely to be organic. Hence, the combination of the arguments about nationality and ecology in the positioning of the brand leads to the higher possibility of purchase intentions of two types of consumers: those who choose organic product, and those who do not prefer organic products.

The results of this research enhance understanding of the holistic view of brand associations' effect on consumer behaviour. In such a way, the findings of this investigation complement those of earlier studies by revealing the influence of brand associations on purchase intentions in the case of organic products. Furthermore, this research of the effect of brand associations on purchase intentions contributes to the literature by integrating both traditional marketing research methods, i.e. questionnaire research and neuromarketing research methods, i.e. response latency measure in order to objectively analyse and evaluate consumer behaviour. Hence, the framework of this research will serve as a base for future studies.

Moreover, the findings of this study have specific practical implications: by following research results, organizations can improve their brand equity by enhancing effective positioning possibility, which in turn can enhance brand value resulting in the improved sales. Directions for the future research are the analysis of the influence of brand associations on the conative consumer response in the frameworks of the products of remaining categories.

\section{References}

1. Till, B.D., Baack, D., \& Waterman, B. (2011). Strategic brand association maps: developing brand insight. Journal of Product \& Brand Management. 20(2), 92 - 100. DOI: 10.1108/10610421111121080.

2. Liesionis, V., \& Pilelienè, L. (2009). Influence of the Ecological Factors on Consumers' Choice. Management of Organizations: Systematic Research. 52, $49-61$.

3. Pilelienè, L., Grigaliūnaitè, V., \& Stakauskaitè, G. (2016). Produkto pakuotès spalvos įtaka impulsyviems pirkimams (The influence of product packaging colour on impulsive buying behaviour). Organizaciju vadyba: sisteminiai tyrimai. 76, 107 - 116. DOI: 10.7220/MOSR.2335.8750.2016.76.7. (in Lithuanian).

4. Pilelienè, L., \& Liesionis, V. (2014). Influence of product attributes on milk consumer's choice in Lithuania. In Research for rural development: annual 20th international scientific conference proceedings, $21-23$ May 2014 (Vol. 2, pp. 223 - 228). Jelgava: Latvia University of Agriculture.

5. Pilelienè, L., \& Šntaitè-Petkevičienè, M. (2014). The effect of country-of-origin on beauty products choice in Lithuania. Procedia - social and behavioral sciences. 156, 458 - 462. DOI: 10.1016/j. sbspro.2014.11.221.

6. Šntaitè-Petkevičienè, M., \& Pilelienè, L. (2013). The impact of country-of-origin on food products choice. In Changes in social and business environment: proceedings of the 5th international conference, 7 - 8 November 2013 (pp. 189 - 196). Lithuania: Kaunas University of Technology Panevėžys institute.

7. Virutamasen, P., Wongpreedee, K., \& Kumnungwut, W. (2015). Strengthen Brand Association through SE: Institutional Theory Revisited. Procedia - Social and Behavioral Sciences. 195, 192 - 196. DOI: 10.1016/j.sbspro.2015.06.348. 